\title{
PROBLEMATYKA BADAWCZA TEOLOGII DOGMATYCZNEJ W „COLLECTANEA THEOLOGICA” 1920-2020
}

Jubileusz stulecia istnienia wiodącego polskiego czasopisma teologicznego, jakim jest „Collectanea Theologica”, stanowi zachętę do podjęcia próby ukazania, jak badania z dziedziny teologii dogmatycznej rozwijały się dzięki publikacjom na łamach tego czasopisma, jakie koncepcje teologiczne były tutaj formułowane, jaki kształt metodologiczny przybierały podejmowane prace, jacy autorzy w szczególny sposób odcisnęli swoje piętno na podejmowanej tutaj teologicznej refleksji. Ze względu na obfitość i różnorodność badanego materiału nie wszystkie zagadnienia zostaną omówione w sposób wyczerpujący.

\section{Historia jako żywa rzeczywistość}

W okresie funkcjonowania badanego czasopisma można wyróżnić pewne etapy rozwoju. Pierwszym z nich jest okres międzywojenny (1920-1939), trudny początek czasopisma wychodzącego w kraju, który dopiero odzyskał niepodległość. Charakterystyczną cechą tego czasu wydaje się mocne oparcie na myśli wielkich teologów ze szczególnym uwzględnieniem św. Augustyna ${ }^{1}$ i św. Tomasza. ${ }^{2}$

A. Słomkowski, Charakter darów stanu pierwotnego wedlug nauki św. Augustyna, Przegląd Teologiczny 11(1930) nr 4, s. 57-75; tenże, Relatui gratiam sanctificantem inter et iustitiam originalem secundum doctrinam s. Augustini, Collectanea Theologica (dalej: CT) 18(1937) nr 1/2, s. 32-52.

2 Tenże, Nauka św. Tomasza z Akwinu o niewidzialnych posłannictwach Osób Boskich, CT 17(1936) nr 1-2, s. 94-142; M. Dietz, Dogmat stworzenia wedle 
W okresie tym publikował Maciej Sieniatycki (1869-1949) kierujący katedrą dogmatyki na Uniwersytecie Jagiellońskim w latach 1909-1935. W swoich wykładach wprowadził język polski na miejsce wcześniej używanej łaciny. Dzięki jego podręcznikom (m.in. Zarys dogmatyki katolickiej) ustalona została polska terminologia w dziedzinie teologii dogmatycznej. ${ }^{3} \mathrm{~W}$ jednej ze swoich prac wskazuje na rozumienie Kościoła przez Ojców Apostolskich. Podkreśla występujące u nich rozróżnienie na Kościół widzialny i niewidzialny. W tym drugim znaczeniu można mówić o przynależności nie tylko wiernych żyjących, ale i zmarłych a także świętych, którzy żyli przed Chrystusem, od początku istnienia ludzi na ziemi. ${ }^{4}$

Andrzej Cichowski próbował zarysować problematykę rozwoju nauk teologicznych w Polsce. Przypomniał m.in. postacie Wojciecha Sokołowskiego (1586-1631), Marcina Śmigleckiego (1563-1618), Justyna Zapartowicza (†1649). Zauważył, że H. Hurter w swoim dziele Nomenclator litterarius theologiae catholicae (1903-1913) podał wykazy prac kilkudziesięciu polskich teologów. ${ }^{5}$ Zwięźle o rozwoju teologii polskiej XIX i XX w. pisał Aleksy Klawek. ${ }^{6}$

Stanisław Frankl (1903-1944) zajmował się m.in. badaniem koncepcji ofiary mszy św. sformułowanej przez kard. Stanisława Hozjusza (1504-1579), ${ }^{7}$ polskiego teologa XVI w., który, jako legat

św. Tomasza z Akwinu, Przegląd Teologiczny 5(1924) nr 2-3, s. 125-142; A. Żychliński, Nauka św. Tomasza z Akwinu o naturze łaski działającej, Przegląd Teologiczny 9(1928) nr 4, s. 347-366; F. Lisowski, Św. Tomasz z Akwinu o rozwoju dogmatów, Przegląd Teologiczny 5(1924) nr 2-3, s.161-174.

3 M. Rechowicz (red.),Dzieje teologii katolickiej w Polsce, t. III: Wiek XIX i XX, cz. I, Lublin 1976, s. 162; S. Piech, Maciej Sieniatycki, https://www.ipsb.nina. gov.pl/a/biografia/maciej-sieniatycki?print (dostęp: 10 III 2020).

4 M. Sieniatycki, Nauka Ojców Apostolskich o Kościele, Przegląd Teologiczny 3(1922) nr 1, s. 31-52.

5 A. Cichowski, O historji nauk teologicznych $w$ Polsce, CT 17(1936) nr 3, s. 394-395, 398.

6 A. Klawek, De scientiarum sacrarum in Polonia progressu, CT 18/(1937) nr 1-2, s. 541-563.

7 S. Frankl, Doctrina Hosii de sacrificio Missae cum decreto Tridentino comparata, CT 16(1935) nr 3, s. 281-339. 
papieski, uczestniczył w ostatniej sesji Soboru Trydenckiego. Frankl był rektorem seminarium duchownego we Lwowie i wykładowcą na Wydziale Teologicznym Uniwersytetu Jana Kazimierza. Podczas II wojny światowej brał udział w tajnym nauczaniu i przygotował do święceń kapłańskich ok. 60 kleryków. Aresztowany przez Niemców i torturowany, został odbity przez Armię Krajową. Po doświadczeniach więziennych nie odzyskał zdrowia i zmarł, ukrywając się przed prześladowcami. $^{8}$

Drugi etap rozwoju badań z teologii dogmatycznej przypada na lata między reaktywowaniem wydawania „Collectanea Theologica” po II wojnie światowej a początkiem II Soboru Watykańskiego (1949-1961). Teolodzy pracowali w tym czasie w kraju poddanym naciskowi ateistycznej ideologii i komunistycznej cenzurze. W okresie tym podejmowana była przede wszystkim problematyka istnienia Boga, ${ }^{9}$ zagadnienia mariologiczne ze szczególnym uwzględnieniem wniebowzięcia Najświętszej Maryi Panny ${ }^{10}$ oraz kwestie metodologii. ${ }^{11}$

Trzeci etap, obejmujący lata 1962-1990, odznacza się szczególnym bogactwem zagadnień i autorów. Początkowo podejmowana jest przede wszystkim problematyka soborowej eklezjologii, ale już od przełomu lat sześćdziesiątych i siedemdziesiątych można dostrzec

8 „Biała księga”. Martyrologium duchowieństwa-Polska XX w. (lata 1914-1989), http:/www.swzygmunt.knc.pl/MARTYROLOGIUM/POLISHRELIGIOUS/ vPOLISH/HTMs/POLISHRELIGIOUSmartyr0621.htm (dostęp: 10 III 2020).

9 I. Różycki, Dowód teleologiczny na istnienie Boga, CT 26(1955) nr 3, 415 -464; J. Stroba, Poznanie Boga w „Myślach” Pascala, CT 24(1953) nr 1-4, s. 57-66.

10 A. Pawłowski, De doctrina Assumptionis Deiparae definienda: quaestiones selectae, CT 21(1949) nr 1, s. 1-15; L. A. Krupa, Świętość Niepokalanej i Wniebowziętej Matki Zbawiciela, CT 25(1954) nr 3, s. 361-398; W. Pietkun, Dwie drogi rozwoju dogmatu o Niepokalanym Poczęciu Najświętszej Maryi Panny, CT 25(1954) nr 3, s. 423-438; I. Różycki, De Beatae Mariae Virginitate in partu, CT 25(1954) nr 3, s. 439-467; W. Miziołek, Stosunek teologii dialektycznej K. Bartha do mariologii, CT 25(1954) nr 3, s. 523-564.

11 I. Bocheński, O metodzie teologii w świetle logiki współczesnej, CT 21(1949) nr 2-3, s. 171-192; I. Różycki, De theologica significatione analogiae, CT 27/1956, s. 53-58; tenże, Epistemologiczna analiza wiedzy o Bogu, CT 28(1957) nr 1, s. 66-86. 
wielość zagadnień takich jak: personalistyczne ujęcie wcielenia, ${ }^{12}$ pytanie o cierpienie Boga, ${ }^{13}$ teologia słowa Bożego, ${ }^{14}$ znaki czasu, ${ }^{15}$ teologia wolności, ${ }^{16}$ charyzmat teologa,${ }^{17}$ teologia odpoczynku, ${ }^{18}$ problem mikrohistorii, ${ }^{19}$ teologia rzeczywistości ziemskich, ${ }^{20}$ teologia przestrzeni.

Czwarty okres (1991-2020) odznacza się wyraźnie mniejszą obecnością teologii dogmatycznej na łamach „Collectanea Theologica”. Jednak także w tym okresie można dostrzec cenne publikacje dotyczące m.in. teologii czasu, ${ }^{21}$ literatury chrystoforycznej ${ }^{22}$ czy polskiej teologii ikony. ${ }^{23}$ Podejmowano dyskusje dotyczące nadziei powszechnego zbawienia, ${ }^{24}$ hipotezy ostatecznej decyzji w momencie śmierci, ${ }^{25}$ tożsamości kapłana ${ }^{26}$ czy inteligentnego projektu.

12 Cz. Bartnik, Bóg człowiekiem, CT 58(1988) nr 4, s. 5-16.

13 W. Hryniewicz, La souffrance de Dieu: quelques réflexions préliminaires, CT 51 (1981) fasc. spec., s. 115-135.

14 S. C. Napiórkowski, „Narzędzie oraz instrument Ducha Świętego”: przyczynek do teologii słowa Bożego, CT 45(1975) nr 2, s. 65-73.

15 S. Moysa, Znaki czasu a rozeznanie duchowe, CT 47(1977) nr 4, s. 23-44.

16 Cz. Bartnik, Wolność wyzwolona, CT 50(1980) nr 4, s. 27-41.

17 R. Rogowski, Charyzmat teologa, CT 48(1978) nr 3, s. 5-17.

18 J. Salij, Teologiczny sens odpoczynku niedzielnego, CT 39(1969) nr 3, s. 5-18.

19 Cz. Bartnik, Le problème de l'histoire de l'individu, CT 54 (1984) fasc. spec., s. $29-40$.

20 J. Lewandowski, Teologia rzeczywistości ziemskich, CT 69(1999) nr 3, s. 71-84.

21 P. Liszka, Styk czasu z wiecznościa w misterium Chrystusa, CT 63(1993) nr 1, s. 80-83.

22 J. Szymik, Literatura chrystoforyczna. Spór wokót teologicznych założeń i implikacji, CT 63(1993) nr 4, s. 67-77.

23 S. C. Napiórkowski, Polska teologia ikony? Problem obecności Maryi pośród nas $w$ świetle doświadczeń peregrynacji, CT 61(1991) nr 4, s. 23-43.

24 I. Bokwa, Powszechna nadzieja zbawienia wedtug Hansa Urs von Balthasara, CT 62(1992) nr 4, s. 79-88.

25 A. Dańczak, Losy Endentscheidungshypothese L. Borosa: próba retrospekcji, CT 79(2009) nr 3, s. 59-80.

26 M. Jagodziński, Trwały skutek przyjęcia sakramentu święceń, CT 74(2004) nr 3, s. 77-89. 
Teologia dogmatyczna jest zanurzona w historii. Ważnym jej miejscem teologicznym są pisma Ojców Kościoła. Nie można zapomnieć o pracy Doktorów Kościoła. Teolog nie zaczyna pracy od własnej osoby, ale jest świadomy osiągnięć i porażek swoich poprzedników. Jest ciekawy stawianych przez nich problemów, stosowanych metod badawczych, uzyskiwanych wyników. Istnieje nauczanie teologów, którego pewnym niewielkim fragmentem są także prace autorów publikujących wyniki swoich badań na łamach „Collectanea Theologica”.

\section{Twórczy dialog interdyscyplinarny}

Chronologicznie pierwszym dogmatykiem publikującym na łamach „Collectanea Theologica” był Andrzej Macko (1871-1921), który uzyskał doktorat z teologii na Uniwersytecie Gregoriańskim w Rzymie, a następnie wykładał jako profesor Instytutu Teologicznego w Tarnowie. ${ }^{27}$ Autor ten podjął zagadnienie treści teologicznych zawartych w Dziadach Adama Mickiewicza. W utworze tym widział przede wszystkim prawdę o obcowaniu świętych. We wstępie do swojej pracy Macko wymienia niektórych polskich poetów (m.in. Kochanowski, Sarbiewski, Karpiński, Krasiński, Słowacki, Konopnicka, Wyspiański) podejmujących tematy teologiczne, zachęcając do sięgnięcia ku ich twórczości przy wyjaśnianiu problematyki teologii dogmatycznej. ${ }^{28}$

Cenną wrażliwość metodologiczną spotykamy w twórczości Jerzego Szymika, w latach 2004-2014 członka Międzynarodowej Komisji Teologicznej. Zastanawia się on nad rozumieniem pojęcia sacrum i metodologią badania sacrum w literaturze. Rozważa zalety i wady koncepcji literatury chrystoforycznej. Nie ograniczając się do

27 H. E. Wyczawski (red.), Stownik polskich teologów katolickich, t. 3, Warszawa 1982, s. 30.

28 A. Macko, Teologia w „Dziadach” Mickiewicza, Przegląd Teologiczny 1(1920) $\mathrm{nr} \mathrm{1,} \mathrm{s.} \mathrm{13-15.}$ 
kwestii ściśle metodologicznych, stawia pytania, czym jest w swej istocie chrześcijaństwo i chrześcijańska kultura. ${ }^{29}$

Jacek Salij OP zachęca do konfrontacji zagadnień teologicznych z problemami i rozwiązaniami występującymi w innych naukach, szczególnie humanistycznych. Rozważając kilka ujęć problemu przeznaczenia (Rudolfa Otto, Maxa Webera czy Ericha Fromma), dostrzega w ich krytyce ziarno prawdy. Chociaż ujęcia te ujmowane całościowo są nie do przyjęcia w teologii katolickiej ze względu na płaszczyznę naturalistyczną, relatywizm i moralizm, to jednak podejmują realnie istniejące problemy. Człowiek może przeżywać ortodoksyjną wiarę w różny sposób, mniej lub bardziej prawdziwy, niekiedy bardzo uwikłany w swoją grzeszność. ${ }^{30}$

W dialogu z filozofią i naukami przyrodniczymi podejmuje teologiczną refleksję nad przestrzenią Czesław Stanisław Bartnik (1931-2020). Wskazuje na znaczenie podstawowych biblijnych terminów dotyczących wspomnianej problematyki, na różne rodzaje przestrzeni zarówno wynikającej z samej rzeczywistości bytów, jak i współtworzonej przez człowieka. Przypomina o, związanym z myśleniem o Bogu, rozumieniu przestrzeni przez I. Newtona, S. Clarka, B. Spinozę czy A. Einsteina. Wśród koncepcji ogólnego kształtu czasoprzestrzeni (statyczna, repetycyjna, ewolucyjna) wskazuje na znaczenie modelu wrzecionowatego lub stożkowo-omegalnego (w ramach koncepcji ewolucyjnej) jako możliwego miejsca dialogu teologii i nauk przyrodniczych. ${ }^{31}$

29 J. Szymik, Literatura chrystoforyczna. Spór wokót teologicznych założeń i implikacji, CT 63(1993) nr 4, s. 67, 74, 76. Wspomniany teolog jest autorem wielopłaszczyznowego ujęcia zagadnienia literatury pięknej jako miejsca teologicznego; tenże, W poszukiwaniu teologicznej głębi literatury. Literatura piękna jako locus theologicus, Katowice 2007.

30 J. Salij, Pozateologiczne interpretacje doktryny o przeznaczeniu, CT 43(1973) nr 3, s. 5-6, 19, 21.

31 Cz. Bartnik, Zarys teologii przestrzeni, CT 54(1984) nr 4, s. 21-37; tłum. franc.: Cz. Bartnik, Esquisse de la théologie de l'espace, CT 55(1985) fasc. spec., s. 129-145. 
W pracach wspomnianych autorów, należących do różnych pokoleń, istnieje otwartość na pytania formułowane poza granicami teologii, odwaga podejmowania trudnych problemów, próby odpowiedzi na niebanalne kwestie. Odwaga ta łączy się z jasnością języka który nie próbuje uciekać w pseudoerudycję - oraz metodologiczną rzetelnością.

\section{Zainteresowanie myślą chrześcijańskiego Wschodu}

W pracach niektórych teologów dogmatyków, publikujących w „Collectanea Theologica”, znajduje swój wyraz twórcze zainteresowanie myślą teologiczną i kulturą chrześcijańskiego Wschodu. Wspomniane czasopismo do 1939 r. ukazywało się we Lwowie stanowiącym miejsce spotkania wielu kultur, narodów i wyznań.

Antoni Pawłowski (1903-1968), profesor teologii na Uniwersytecie Warszawskim i Wileńskim, uzyskał doktorat z dogmatyki (1929) na podstawie rozprawy Dogmat Niepokalanego Poczęcia w oświetleniu nowszych prawosławnych teologów rosyjskich. Podczas okupacji aresztowany i w latach 1942-1944 więziony przez Niemców. Od 1953 r. jako biskup kierował diecezją włocławską. Uczestniczył w II Soborze Watykańskim. ${ }^{32}$ W 1937 r. opublikował cenną pracę dotyczącą sofiologii Włodzimierza Sołowiewa. ${ }^{33}$

Znaczącą część swojej pracy teologicznej poświęcił myśli Sołowiewa Stanisław Napierała, biskup diecezji kaliskiej (1992-2012). W Wielkim sporze i chrześcijańskiej polityce dostrzegł ważną koncepcję jedności Kościoła. Sołowiew przyznaje dużą wartość widzialnej jedności Kościoła, uznaje autorytet biskupa rzymskiego

32 Z. Zieliński, Antoni Pawłowski, w: E. Rostworowski (red.), Polski Stownik Biograficzny, t. XXV, Wrocław-Warszawa-Kraków-Gdańsk 1980, s. 488-489.

33 A. Pawłowski, Sofiologia Włodzimierza Sołowiewa, CT 18(1937) nr 1-2, s. 133-200. Ten sam autor napisał ważną pracę o rozumieniu Kościoła w teologii i historiozofii rosyjskiej, w której omówił nauczanie większości znaczących rosyjskich teologów (m.in. M. Bułgakowa, A. Chomiakowa, S. Bułgakowa, W. Sołowiewa); tenże, L'idée de l'Église: d'après la théologie et l'historiosophie russes, CT 15(1934) nr 4, s. 494-519. 
w Kościele powszechnym, dostrzega zarówno we wschodniej, jak i zachodniej kulturze wartości autentycznie chrześcijańskie. Zachęca do przywrócenia widzialnej jedności kościelnej opartej na racjach religijnych i moralnych, do opartego na poszukiwaniu prawdy dialogu doktrynalnego. ${ }^{34}$

Andrzej Zuberbier (1922-2000) wzywał do rozwijania teologii ekumenicznej, czyli zwrócenia całej teologii ku pragnieniu zjednoczenia chrześcijaństwa. W tym celu konieczne jest lepsze poznanie doktryny niekatolickiej, w szczególności teologii wschodniej zakorzenionej w Piśmie Świętym, zasilanej pismami Ojców wschodnich, wspartej bogatą spuścizną duchową i liturgiczną. Potrzebne jest bardziej całościowe przedstawienie tej teologii z uwzględnieniem historii doktryny w duchu zrozumienia i życzliwości. Jednocześnie należy formułować teologiczną doktrynę katolicką w sposób i zrozumiały, i pełny, unikając niebezpieczeństwa fałszywego irenizmu. ${ }^{35}$

Ekspert teologii prawosławnej, Wacław Hryniewicz, wskazuje na żywą obecność w tej teologii idei chrystocentryzmu połączonej z pneumatologią, na generalnie pozytywną ocenę katolickiego i protestanckiego chrystocentryzmu, ale zwraca też uwagę na obawy prawosławnych związane z chrystomonizmem, w którym brakuje realnego związku z doktryną trynitarną. ${ }^{36}$

\section{Wydarzenie II Soboru Watykańskiego}

Zmarły w opinii świętości dogmatyk Wincenty Granat (1900-1979), rektor KUL, opublikował w 1966 r. szkic analizy Lumen gentium, wskazując na tendencję biblijną i duszpasterską tego dokumentu, jego ekumenizm i uniwersalizm, a także całościowe ujęcie rzeczywistości Kościoła istniejącego już w odwiecznych planach

34 S. Napierała, Wizja jedności Kościoła w ,Wielkim sporze” Włodzimierza Sołowiewa, CT 40(1970) nr 1, s. 49-62.

35 A. Zuberbier, Teologia wobec ekumenizmu, CT 36(1966) nr 1-4, s. 221-232.

36 W. Hryniewicz, The centrality of Christ in orthodox theology, CT 46(1976) fasc. spec., s. 153-168. 
Bożej opatrzności. Za najważniejszy element dokumentu uznał troskę o ewangeliczną miłość. W szczególny sposób wyraziła się ona w powszechnym wezwaniu do świętości w Kościele, czyli do miłości Boga i bliźniego. ${ }^{37}$

Przez kilkadziesiąt lat (1966-1990) redaktorem naczelnym „Collectanea Theologica” był Henryk Bogacki SJ (1924-1993). Z jego inicjatywy zaczął ukazywać się obcojęzyczny numer specjalny czasopisma, ułatwiający wymianę myśli polskiej teologii ze środowiskiem międzynarodowym. Jako energiczny dyrektor wydawnictwa ATK redagował prace naukowe, m.in. w ramach takich serii, jak ,Studia Teologiczno-Dogmatyczne". ${ }^{38}$ Był autorem licznych recenzji niemieckich, angielskich i francuskich dzieł teologicznych. W swoich publikacjach starał się przybliżać nauczanie soborowe, m.in. dotyczące charyzmatów jako rzeczywistości współczesnego Kościoła. ${ }^{39}$

Kardynał Karol Wojtyła, późniejszy papież Jan Paweł II, dzieląc się doświadczeniem swojej pracy w komisji przygotowującej schemat XIII Kościół w świecie współczesnym, czyli późniejszą konstytucję Gaudium et spes, starał się na łamach „Collectanea Theologica” ukazać związek II Soboru Watykańskiego z wysiłkiem teologów. Przez liczne prace teologiczne, w prawie stuletnim okresie od Vaticanum I do Vaticanum II, niejako umożliwili oni powstanie sformułowań ostatniego Soboru. Podczas Vaticanum II pełnili funkcję ekspertów (periti). Po Soborze są wezwani do zbadania możliwie pełnego kontekstu Vaticanum II, do zobaczenia w nim całości doktrynalnej, ale także całości wydarzeniowej. Teologia ma za zadanie w sposób naukowy wyjaśniać zawartość objawienia i z tego wynika troska teologów o poprawność, ścisłość, precyzję, gruntowność,

37 W. Granat, Konstytucja dogmatyczna: „Lumen gentium” Soboru Watykańskiego II, CT 36(1966) nr 1-4, s. 47-73.

38 J. Salij, Krótkie spojrzenie na warszawska teologię katolicka w ostatnich dwustu latach, w: M. Butkiewicz, J. Slawik, J. A. Sobkowiak (red.), 200 lat teologii uniwersyteckiej w Warszawie, Warszawa 2017, s. 39; J. Charytański, Ks. Henryk Bogacki SJ-profesor-administrator-przyjaciel, CT 64(1994) nr 3, s. 7-8.

39 H. Bogacki, Nauka Vaticanum II o charyzmatycznej strukturze Kościoła, CT 43(1971) nr 3, s. 91-94. 
metodyczną rzetelność mającą wielkie znaczenie dla Kościoła i stanowiącą pomoc dla papieży i biskupów. ${ }^{40}$

Jednym z najważniejszych wydarzeń dla Kościoła i teologii ostatnich stu lat był II Sobór Watykański. Wydarzenie Soboru, jego nauczanie, wyzwanie, jakie stanowi on dla kształtu współczesnej teologii, znajduje swój wyraz w wielu publikacjach ukazujących się na łamach „Collectanea Theologica”.

\section{Poznanie Boga ze szczególnym uwzględnieniem tajemnicy Miłosierdzia Bożego}

Wskazując ważne postacie polskiej teologii dogmatycznej XX w., nie można pominąć Ignacego Różyckiego (1911-1983). Jako profesor Uniwersytetu Jagiellońskiego uczył Karola Wojtyłę i był promotorem jego rozprawy magisterskiej. Jako ekspert soborowy brał udział w pracach nad Deklaracja o wolności religijnej oraz Konstytucja duszpasterska o Kościele w świecie współczesnym. ${ }^{41}$ W latach 1980-1983 był członkiem Międzynarodowej Komisji Teologicznej. W jego pracach zwraca uwagę rzetelna troska o problematykę epistemologiczną opartą na myśli tomistycznej. Analizując możliwości analogicznych wypowiedzi o Bogu (cognitio analogica), podkreśla prawdę o nieskończonym niepodobieństwie między Bogiem a stworzeniem. Wskazuje, że teolog - zarówno w teorii, jak i w praktyce-powinien uwzględniać, że niepodobieństwo między Bogiem a stworzeniami jest zawsze większe od podobieństwa, a więc praktycznie powinien wskazywać, na czym to niepodobieństwo polega. ${ }^{42}$

Pod kierunkiem Ignacego Różyckiego doktorat z teologii dogmatycznej na Uniwersytecie Jagiellońskim uzyskał Jerzy Stroba (1919-1999), późniejszy biskup diecezji szczecińsko-kamieńskiej,

\footnotetext{
40 K. Wojtyła, Vaticanum II a praca teologów, CT 36(1966) nr 1-4, s. 8-14.

41 J. Salij, Krótkie spojrzenie na warszawska teologię katolicka w ostatnich dwustu latach, s. 38-39.

42 I. Różycki, Epistemologiczna analiza wiedzy o Bogu, s. 66-71, 79-80.
} 
a następnie arcybiskup i metropolita poznański. ${ }^{43}$ Jest on autorem dość wnikliwej interpretacji problematyki poznania Boga w Myślach Pascala. Obok fragmentów odrzucających możliwość rozumowego poznania Boga dostrzega wypowiedzi przyjmujące taką możliwość (p. 556, 288). Uważa, że można uzgodnić te rozbieżności dzięki rozróżnieniu przez Pascala deistycznego i chrześcijańskiego pojęcia Boga, a także perspektywy praktycznej i teoretycznej. Rozumowe poznanie Boga według Pascala ma prowadzić jedynie do Boga pojętego deistycznie, które to poznanie pozostaje nieużyteczne dla zbawienia. $^{44}$

Na łamach „Collectanea Theologica” publikował w okresie międzywojennym dogmatyk Antoni Słomkowski (1900-1982), rektor KUL (1944-1951), więziony przez komunistów w latach 1952-1954. ${ }^{45}$ Jednym $\mathrm{z}$ ważnych tematów jego pracy teologicznej była problematyka trynitarna. ${ }^{46}$

Pewne poczucie niedosytu pozostawiają publikacje dotyczące Ducha Świętego. Trzecia Osoba Trójcy Świętej jest omawiana raczej w perspektywie odnowy świata ${ }^{47}$ czy tajemnicy Kościoła. Ujęcie tajemnicy Ducha Świętego występuje niezbyt często ${ }^{48}$ i raczej nie cechuje się oryginalnością spojrzenia.

Obecna w Biblii prawda o Miłosierdziu Bożym została na nowo odkryta w XX w., m.in. dzięki prywatnym objawieniom św. Faustyny Kowalskiej i pracy teologicznej jej spowiednika bł. Michała Sopoćko

43 J. Dziwoki, Jerzy Stroba, w: A. Romanowski (red.), Polski Słownik Biograficzny, t. XLIV, Warszawa-Kraków, 2006-2007, s. 325-328.

44 J. Stroba, Poznanie Boga w „Myślach” Pascala, s. 57-66.

45 Słomkowski, znany z prostoty i ubóstwa, jako rektor, przekazywał co najmniej połowę swoich dochodów biednym studentom; J. Warzeszak, Ks. Antoni Słomkowski 1900-1982. Rektor i odnowiciel KUL, teolog-rekolekcjonista, człowiek sumienia, Warszawa 1999, s. 19, 63, 64, 71, 114.

46 A. Słomkowski, Nauka św. Tomasza z Akwinu o niewidzialnych posłannictwach Osób boskich, s. 94-142; tenże, Doctrina semiarianorum de circuminsessione personarum ss. Trinitas, CT 16(1935) nr 1, s. 95-103.

47 A. Nossol, Dimension pneumatologique de l'oeuvre du renouveau du monde, CT 53(1983) fasc. spec., s. 5-15.

48 R. Karwacki, Spiritus Paraclitus, CT 59(1989) nr 2, s. 35-42. 
(1888-1975). Teolog ten znany jest przede wszystkim jako autor czterotomowej pracy Miłosierdzie Boga w dziełach Jego (1959-1967). Jako zwolennik kultu Miłosierdzia Bożego doświadczył wielu trudności, m.in. został pozbawiony możliwości nauczania w seminarium duchownym w Białymstoku. ${ }^{49}$ „Collectanea Theologica” już w 1937 r. zauważyła publikację tego autora i zachęcała do korzystania z niej..$^{50}$

Lucjan Balter (1936-2010) przypomina dynamiczny rozwój kultu Miłosierdzia Bożego w ostatnich latach międzywojennych i w okresie II wojny światowej. Już w czasie wojny wspomniany kult pojawił się nawet w Japonii, Palestynie, Australii czy obu Amerykach. Notyfikacja Kongregacji św. Oficjum z 6 marca 1959 r., zakazująca tego kultu w formach zaproponowanych przez s. Faustynę, spowodowała usunięcie obrazów Chrystusa Miłosiernego z katolickich świątyń. Jednak od 1966 r. zaczęto organizować w Częstochowie, a później w Ołtarzewie, sympozja teologiczne poświęcone różnym aspektom tej problematyki, m.in. relacji między Miłosierdziem Bożym a zbawieniem, życiem wiecznym i pokojem. Ksiądz Balter jest świadomy formułowanych trudności dotyczących oddawania osobnej czci jednemu z przymiotów Bożych, a także problemów liturgicznych związanych z ustanowieniem osobnego święta w Niedzielę Oktawy Wielkanocy, ale wskazuje na możliwe rozwiązania i na racje przemawiające za stosownością wprowadzenia tego święta. ${ }^{51}$

Pomysłodawcą wspomnianych sympozjów był ówczesny bp Karol Wojtyła. To on, jako papież Jan Paweł II, poświęcił temu zagadnieniu swoją drugą encyklikę Dives in misericordia (1980), a w 2000 r.

49 T. Krahel, Michat Sopoćko, w: H. Markiewicz (red.), Polski Słownik Biograficzny, t. XL, Warszawa-Kraków 2000-2001, s. 497-501.

50 M. Sopoćko, Miłosierdzie Boże. Studium Teologiczno-praktyczne, Wilno 1936; rec. CT 18(1937) nr 3-4, s. 748.

51 L. Balter, Teologiczno-pastoralne uzasadnienie kultu oraz święta Miłosierdzia Bożego, CT 51(1981) nr 2, s. 25-51; tłum. niem. L. Balter, Pastoraltheologische Begründung des Kultes und des Festes der Barmherzigkeit Gottes, CT 52(1982) fasc. spec., s. 53-76. 
ogłosił w Kościele powszechnym drugą niedzielę wielkanocną świętem Miłosierdzia Bożego. ${ }^{52}$

Rozwój teologii Miłosierdzia Bożego jest przykładem teologicznego dojrzewania, które dokonuje się w Kościele nie w postawie buntu wobec Magisterium, ale w postawie modlitwy, pracy naukowej i cierpienia. Stanowi ona odpowiedź na potrzeby współczesnego świata doświadczającego w szczególny sposób tajemnicy zła, które uwidoczniło się tak wyraźnie w zbrodniach nazizmu i komunizmu.

\section{Tajemnica Chrystusa}

W okresie międzywojennym na łamach „Collectanea Theologica” publikował Władysław Lohn SJ (1889-1961), wykładowca teologii dogmatycznej na Gregorianum (1928-1934), świadek nawrócenia Rudolfa Hössa, zbrodniczego komendanta niemieckiego obozu koncentracyjnego Auschwitz. Jednym z obszarów badań wspomnianego teologa była tajemnica wcielenia. ${ }^{53}$

Teologiczną refleksję nad czasem w kontekście chrystologii podejmuje w swoich pracach Piotr Liszka. Zastanawia się, czy monofizytyzm i nestorianizm nie są związane z określonym sposobem pojmowania czasu. Rozważając styk czasu z wiecznością w Misterium Chrystusa, zachęca do dynamicznego ujęcia wydarzenia wcielenia, dzięki czemu możemy bardziej plastycznie oddać zagadnienie przenikania się natury boskiej i ludzkiej bez ich zmieszania. Jednocześnie nieco krytycznie ocenia teorię Teilharda de Chardin, widząc w niej problem niewystarczającego ukazania autonomii boskości i człowieczeństwa Chrystusa. ${ }^{54}$

52 P. Warchoł, Teologio Polska! Jaka byłaś? Jaka jesteś? Wybrane aspekty współczesnej teologii w Polsce, Teologia w Polsce 1(2017) nr. 1, s. 89-90.

53 W. Lohn, Doctrina Nestorii de mysterio Incarnationis, CT 14(1933) nr 1-2, s. $1-37$.

54 P. Liszka, Styk czasu z wiecznością w misterium Chrystusa, CT 63(1993) nr 1, s. 80-83. Szersze ujęcie teologii czasu tego autora mające znaczenie szczególnie dla eschatologii w: tenże, Wpływ nauki o czasie na refleksję teologiczna, Wrocław 1992. 
Alfons Nossol, biskup opolski w latach $1977-2009,{ }^{55}$ podkreśla prymat chrystologii we właściwie rozumianej teologii chrześcijańskiej. Zwraca uwagę na krytycyzm wielu nowych ujęć chrystologicznych wobec tradycyjnego rozumienia zasadniczych sformułowań dogmatu, na formułowane zarzuty esencjalizmu, wertykalizmu i dualizmu. Wskazuje na potrzebę rozwoju współczesnej chrystologii katolickiej w perspektywie uniwersalno-teologicznej, kosmiczno-antropologicznej, historyczno-personalistycznej, eschatyczno-pneumatologicznej oraz metadogmatycznej. Zauważa prace twórców nowych koncepcji chrystologicznych takich, jak: H. U. von Balthasar, W. Breuning, Ch. Duquoc, J. Galot, A. Hulsbosch, W. Kasper, H. Küng, H. Mühlen, J. Nolte, J. Ratzinger, E. Schillebeckx, P. Schoonenberg, H. Schürmann i D. Wiederkehr. ${ }^{56}$

Do odnowy teologii życia Jezusa zachęca Janusz Królikowski. Uważa, że współczesna chrystologia jest zbytnio skoncentrowana na misteriach wcielenia i odkupienia, na formalnych analizach tożsamości Chrystusa, na badaniu tego, co w Jego życiu nadzwyczajne. Tymczasem Chrystus jest Człowiekiem żyjącym w konkretnej historii. Wcielenie i odkupienie nie są jedynymi misteriami, dzięki którym dokonało się zbawienie ludzi. Warto rozwijać zarówno teologię życia Jezusa, jak i teologię poszczególnych misteriów. W szczegółowej refleksji należy zwrócić uwagę na znaczenie danego wydarzenia z życia Jezusa jako misterium, przykładu do naśladowania i normy moralnej. Całościowa teologia życia Jezusa pomaga w spojrzeniu na nasze zwykłe, ludzkie życie jako misterium łaski. ${ }^{57}$

Obecność eschatologii w wydarzeniu Jezusa Chrystusa ukazuje Krzysztof Góźdź, od 2014 r. członek Międzynarodowej Komisji Teologicznej. Wskazuje na wewnętrzny związek chrystologii

55 K. Góźdź (red.), Leksykon polskich dogmatyków XX i XXI wieku, Lublin 2010, s. 267-268.

56 A. Nossol, U podstaw aktualnych dyskusji wokót tajemnicy Chrystusa, CT 46(1976) nr 3, s. 5-16.

57 J. Królikowski, Mysteria vitae Christi a poszukiwania współczesnej chrystologii, CT 60(1990) nr 1, s. 21-31. 
i eschatologii, które nie mogą być właściwie rozumiane w oderwaniu od siebie. W zmartwychwstaniu Pana eschatologia staje się już obecna, aczkolwiek wymaga jednocześnie ludzkiego zaangażowania. W swoich rozważaniach autor nawiązuje do koncepcji Wolfharta Pannenberga. ${ }^{58}$

\section{Pogłębienie teologii maryjnej}

Eugeniusz Florkowski (1902-1989), rektor seminarium w Krakowie i profesor Karola Wojtyły w latach II wojny światowej, opublikował pracę poświęconą mariologii Stanisława z Łowicza, polskiego teologa z początku XVI w., który chciał zachęcić katolików do gorliwego obchodzenia święta Niepokalanego Poczęcia w okresie sporów i rozłamów w Kościele związanych z reformacją. ${ }^{59} \mathrm{~W}$ tych badaniach historycznych możemy dostrzec pragnienie sięgnięcia ku źródłom, a także zwrócenie uwagi na znaczenie mariologii w sytuacji ostrych międzywyznaniowych konfliktów.

Ojciec Bernard Przybylski OP (1907-1979) podczas II Soboru Watykańskiego był doradcą teologicznym kard. Stefana Wyszyńskiego i przyczynił się do opracowania VIII rozdziału Lumen gentium. Przygotował uzasadnienie teologiczne wniosku Episkopatu Polski o nadanie Najświętszej Maryi Pannie tytułu Matki Kościoła. ${ }^{60} \mathrm{Za}$ chęcał do odnowy teologii maryjnej, opierając ją na Pismie Świętym, Tradycji i liturgii, a także silniej wiążąc z całą teologią rozważaną w perspektywie historiozbawczej. Problematykę relacji Maryi i Kościoła ujmował w aspekcie ekonomii zbawienia. Opisywał odkupienie jako działanie Boga, dokonane w Synu i przez Syna, polegające na przywróceniu obecności Boga wśród ludzi. Maryja stała się pierw-

58 K. Góźdź, Gegenwärtigkeit der Eschatologie im Christusereignis, CT 57(1987) fasc. spec., s. 71-89.

59 E. Florkowski, Nauka Stanisława z Łowicza o Niepokalanym Poczęciu Najświętszej Maryi Panny, CT 25(1954) nr 3, s. 399-421.

60 J. Kłoczowski, Bernard Przybylski, w: E. Rostworowski (red.), Polski Słownik Biograficzny, t. XXIX, Wrocław-Warszawa-Kraków-Gdańsk-Łódź 1986, s. 94-96. 
szą osobą, która osiągnęła pełnię osobistego odkupienia w swoim wniebowzięciu. Będąc wzorem złączenia z Chrystusem przez wiarę, stała się Matką wierzących, biorąc czynny udział w przekazywaniu członkom Kościoła pełnej wiary i przygotowując do zjednoczenia z Jezusem Chrystusem. ${ }^{61}$

Jacek Bolewski SJ (1946-2012), profesor Bobolanum, w swojej pracy naukowej najwięcej uwagi poświęcił mariologii. Starał się ukazywać maryjne prawdy o niepokalanym poczęciu i wniebowzięciu jako wypowiedzi naświetlające początek i kres ludzkiego życia. ${ }^{62}$

Ważną rolę w polskiej mariologii odegrał Stanisław Celestyn Napiórkowski OFM, wydawca dziewięciu tomów źródeł mariologicznych, zatroskany o recepcję w zakresie mariologii dokumentów Magisterium Kościoła ze szczególnym uwzględnieniem II Soboru Watykańskiego. ${ }^{63} \mathrm{~W}$ jednym ze swoich artykułów podejmuje problematykę fenomenu nawiedzenia kopii obrazu Maryi Jasnogórskiej w diecezjach, parafiach i rodzinach. Szczególne znaczenie miała pierwsza wielka peregrynacja przez wszystkie polskie parafie, trwająca od 1957 do 1980 r., która przyniosła liczne owoce duszpasterskie. Z tym fenomenem wiąże się teologiczny problem obecności Maryi w jasnogórskiej ikonie, jej kopiach, pustych ramach symbolizujących obraz uwięziony przez komunistów czy wydarzeniach nawiedzeń. W wydarzeniu nawiedzenia zakładana jest określona teologia obecności Maryi, która jednocześnie w tym procesie dojrzewa. Autor dzieli się swoimi zastrzeżeniami wobec niektórych praktyk czy wypowiedzi towarzyszących nawiedzeniom, ale zauważa obfitość duchowych owoców. ${ }^{64}$

61 B. Przybylski, Osiagnięcia polskiej mariologii w ostatnim dwudziestoleciu, CT 37(1967) nr 1, s. 89, 103.

62 K. Góźdź (red.), Leksykon polskich dogmatyków XX i XXI wieku, s. 48; J. Bolewski, Das Assumptio-Dogma und seine Bedeutung für die Eschatologie nach Karl Rahner, CT 58(1988) fasc. spec., s. 89-152.

63 K. Góźdź (red.), Leksykon polskich dogmatyków XX i XXI wieku, s. 255-257.

64 S. C. Napiórkowski, Polska teologia ikony? Problem obecności Maryi pośród nas $w$ świetle doświadczeń peregrynacji, s. 23-43. 
Autorzy podejmujący problematykę mariologiczną starają się na ogół łączyć badania naukowe z szacunkiem dla ludowej pobożności maryjnej mającej w Polsce tak wielkie znaczenie indywidualne i społeczne. Postawa krytyczna nie musi oznaczać pogardliwej wyższości i odrzucenia.

\section{Personalistyczne ujęcie problematyki antropologicznej}

Czesław S. Bartnik, krytycznie oceniając stan współczesnej teologii katolickiej uprawianej na uczelniach, wskazuje na znaczenie personalizmu jako możliwej drogi odrodzenia teologii. Uważa, że oddaje on głębię tajemnicy chrześcijaństwa, jego strukturę w osobie ludzkiej i w społeczności, a pod względem metodologicznym unika błędnych jednostronności, np. spekulatywizmu i historyzmu. ${ }^{65}$

U tego samego autora znajdujemy próbę naszkicowania teologii odpoczynku. Osoba ludzka potrzebuje odpoczynku wobec zmęczenia fizyczno-biologicznego, umysłowego, psychicznego czy społecznego. Przede wszystkim jednak jest transcendentna wobec pracy, przez odpoczynek niejako poczyna się na nowo. Odpoczynek ma znaczenie nie tylko doczesne, ale i religijne. Właściwie pojmowana zabawa ma w sobie coś z radości dzieci Bożych świadomych, że są wezwane ku zbawieniu, a nie skazane na świat pozbawiony nadziei. Najwyższą formą odpoczynku jest świętowanie, czyli przeżywanie sacrum, odnajdywanie w określonym miejscu, czasie i społeczności szczególnego związku z Bogiem, przez które dokonuje się otwarcie człowieka na nieskończoność, odkrywanie prawdziwego sensu ludzkich działań. ${ }^{66}$

Ignacy Dec ukazuje człowieka jako pielgrzyma. Opierając się na Piśmie Świętym, wskazuje na ludzi wybranych przez Boga, którzy zdążają przez ziemię do celu ostatecznego. Pielgrzymującymi postaciami są: Abraham, Józef syn Jakuba, Mojżesz, prowadzący naród wybrany z niewoli egipskiej, prorocy, a w Nowym Testamencie sam

65 Cz. Bartnik, Kryzys teologii współczesnej, CT 61(1991) nr 4, s. 21.

66 Tenże, Chrystianizacja oboczności pracy, CT 52(1982) nr 3, s. 5-15. 
Chrystus Pan, Maryja, uczniowie Chrystusa realizujący nakaz misyjny. Człowiek w Biblii zostaje wezwany do osobowego, duchowego rozwoju, do wzrastania w doskonałości i świętości, do pełniejszego bytowania przez służebną miłość. Istnieje zasadnicza zbieżność między wizją G. Marcela człowieka jako pielgrzyma a perspektywą biblijną. ${ }^{67}$

Do przepracowania dogmatycznego traktatu o Eucharystii w perspektywie antropologicznej zachęca Edward Ozorowski, arcybiskup białostocki (2006-2017). W Eucharystii urzeczywistnia się działanie Boże, dokonujące się w ludziach, działanie uświęcające, przetwarzające, zbawcze. Eucharystia jest nie tylko zewnętrznym darem udzielonym przez Boga, ale przebóstwieniem człowieka. Człowiek należy nieodłącznie do całości sakramentu. ${ }^{68}$

Ważnym zagadnieniem antropologicznym jest kwestia wolności. Można opisywać wolność jako element ontyczny człowieka związany z tajemnicą stworzenia i odkupienia. Ta wewnętrzna struktura osoby przejawia się w realnym ludzkim istnieniu. A konkretniej w dążeniu do uwiecznienia ludzkiej egzystencji, do otwarcia jej na perspektywę wiecznego życia w Bogu, w kontekście poznania jako wolność do odkrycia prawdy, poznania sensu życia, w znaczeniu moralnym jako wolność do dobra i świętości, a w sensie działania jako wolność do tworzenia, rozwoju i samorealizacji. ${ }^{69}$

Oczywiście podkreślanie znaczenia ludzkiej osoby nie powinno prowadzić do jej wyizolowania od innych. Chrześcijańska idea solidarności uwzględnia zarówno osobistą godność człowieka, jak i jego społeczne przeznaczenie, odrzuca i liberalizm, i kolektywizm. ${ }^{70} \mathrm{~W}$ tej sformułowanej w latach trzydziestych refleksji Alojzego Bukowskiego SJ (1873-1941) można dostrzec swego rodzaju

67 I. Dec, ,Homo viator” jako kategoria antropologiczna, CT 52(1985) $\mathrm{nr} 2$, s. 5-18.

${ }^{68}$ E. Ozorowski, Problematyka czlowieka w nauce o sakramencie Eucharystii, CT 44(1974) nr 3, s. 19-25.

${ }^{69}$ Cz. Bartnik, Wolność wyzwolona, s. 28-34.

70 A. Bukowski, Dogmatyczne podstawy chrześcijańskiej solidarności (szkic), CT 16(1935) nr 4, s. 567-584. 
zapowiedź zwycięskiego zmagania Polaków z wyzwaniem ustroju komunistycznego w latach osiemdziesiątych.

\section{Kościół jako communio}

Jak pisze Edward Ozorowski, chrześcijańska communio nie ogranicza się do ludzkich upodobań, ale sięga wewnętrznego życia Trójcy Świętej. Trójjedyny jest źródłem, początkiem i wzorem ludzkiej komunii na płaszczyźnie nadprzyrodzonej. Codzienna realizacja rzeczywistości Kościoła dokonuje się w łączności z całą Trójcą Świętą, na drodze jednoczenia z Bogiem, a w Nim z innymi ludźmi. Celem chrześcijańskiej communio jest ostateczne zjednoczenie w wieczności z Trójcą Świętą, uwzględniające odrębność osób i przynoszące pełnię szczęścia. Communio zmierza do Ojca przez Syna w Duchu Świętym. Już teraz Trójjedyny Bóg jednoczy ludzi na ziemi z poddanymi oczyszczeniu i ze zbawionymi w niebie, umożliwia modlitwę za zmarłych i prośbę o wstawiennictwo świętych. ${ }^{71}$

Communio z Trójcą Świętą jest dziełem Ducha Świętego, będącego węzłem miłości między Ojcem i Synem. Kościół publicznie ujawnił się w dniu Pięćdziesiątnicy, aby głosić, świadczyć i realizować misterium communio Trójcy Świętej. Duch Święty mieszka w Kościele, przemawia, daje świadectwo, przewodzi, jednoczy, obdarza darami. ${ }^{72}$

Podstawową strukturą Kościoła jest Eucharystia. Szczególny rodzaj znaku, jakim jest język eucharystyczny, tworzy interpersonalną komunikację między Bogiem i człowiekiem oraz między ludźmi. W Eucharystii Trójca Święta dociera do społeczności ludzkiej, dokonuje przeistoczenia konkretnej osoby i całego Kościoła wprowadzając nas do swojego Wnętrza. Eucharystia jest źródłem życia Kościoła, który dzięki niej rozwija się, intensyfikuje swoje istnienie. Łączy Kościół pielgrzymujący, oczyszczający się i chwalebny. Komunia

71 E. Ozorowski, Trynitarna struktura chrześcijańskiego „,communio”, CT 41(1971), nr 4, s. 59-66.

72 R. Karwacki, „Communio” eklezjalna jako misterium osobowej jedności z Trójcą Świętą, CT 73(2003) nr 4, s. 53-74. 
Święta jest nie tylko sakramentem jednostki, ale także pokarmem społecznym. Z Eucharystii wypływa szczególna moc kształtowania życia społecznego w duchu ofiarności oraz rezygnacji z przemocy, otwierania historii, kultury, obyczajów, życia gospodarczego, wspólnoty narodowej na obecność Boga. ${ }^{73}$

Czesław S. Bartnik formułuje hipotezę o istnieniu chrztu Kościoła. Uważa, że chrzest, nie przestając być sakramentem jednostki, jest jednocześnie sakramentem społecznym. W opisie chrztu w Jordanie w redakcji Mateusza autor dostrzega chrzest nowego Kościoła przyjęty przez Chrystusa nie ze względu na osobistą potrzebę, ale chrzest Pierworodnego nowego ludu Bożego. Powołując się na Ewangelię św. Jana, zauważa trzy etapy zbawczej realizacji chrztu odpowiadające etapom kształtowania się Kościoła Jezusa Chrystusa - etap początkowy w Jordanie, centralny w ofierze krzyża i końcowy w zesłaniu Ducha Świętego. Według Bartnika chrzest jest jeden i ten sam, ale o różnych wymiarach bytowania. W chrzcie pojedynczej osoby działa i uobecnia się chrzest, jakim Chrystus ochrzcił cały swój Kościół. ${ }^{74}$

Ten sam autor formułuje analogiczną hipotezę bierzmowania Kościoła: Kościół był w swoich początkach bierzmowany jako całość przez zesłanie Ducha Świętego (w ujęciu św. Łukasza). To bierzmowanie stało się podstawą bierzmowania indywidualnego. Można mówić także o bierzmowaniu nowo rodzącego się Kościoła lokalnego niekoniecznie tylko przez bierzmowania jednostkowe jego członków, ale także przez pochodzące od Chrystusa szczególne znaki w konkretnym Kościele. ${ }^{75}$

\section{Tożsamość teologa}

W obliczu krytyki współczesnej teologii, której niejednokrotnie zarzuca się nieprzydatność a nawet brak sensowności jakiejkolwiek

73 Cz. Bartnik, Eucharystia uniwersalna, CT 56(1986) nr 2, s. 5-17; tłum. franc.:

Cz. Bartnik, Eucharistie universelle, CT 56 (1986) fasc. spec., s. 19-32.

74 Tenże, Die Taufe der Kirche, CT 47(1977) fasc. spec., s. 43-56.

75 Tenże, Die Firmung der Kirche, CT 48 (1978) fasc. spec., s. 127-140. 
mowy o Bogu, pojawia się pytanie o miejsce teologa w Kościele i świecie. Roman Rogowski rozróżnia powszechne posłannictwo teologa, które jest właściwe każdemu wierzącemu dokonującemu refleksji nad darem wiary, od specyficznego charyzmatu. Charyzmat ten jest darem Ducha Świętego, polega na darze mądrości i umiejętności poznawania słowa Bożego. Dlatego autentycznym teologiem może być tylko człowiek wierzący, który powinien służyć wierze wspólnoty. Posłannictwo teologa powinno mieć charakter profetyczny, ma on, zgłębiając Boskie misterium, głosić jego aktualność z całym zaangażowaniem, a jednocześnie próbować odpowiadać na najbardziej dramatyczne pytania człowieka. ${ }^{76}$

Podobne przekonanie, że zasadniczym zadaniem teologa jest służba wierze, wyraża Jacek Salij. Właściwe jest korzystanie z osiągnięć innych teologów przez skupianie się i wybieranie przede wszystkim tego, co pogłębia wiarę, czy wręcz ożywianie duchem, tego, co było jedynie uczone. Teolog nie powinien dać się wykorzenić ze swojego środowiska. Należy do ludu, który wierzy, modli się, spowiada i nie chce pochopnie odrzucać tego, czym żył przez wieki. Ale teolog może także przezwyciężać błędy przez uznanie tych niedocenianych wcześniej aspektów prawdy o człowieku, które, niestety, odrzucone przez chrześcijan, stały się źródłem inspiracji ateistycznej. Autor zachęca wreszcie do braterskiej współpracy także z uczonymi Europy Środkowo-Wschodniej - Chorwatami, Węgrami, Rumunami, Czechami, Słowakami czy Litwinami. ${ }^{77}$

Zdzisław Kijas OFM, dziekan PWT św. Bonawentury „Seraphicum” w Rzymie, ${ }^{78}$ podjął refleksję dotyczącą tożsamości współczesnego teologa. Zwrócił uwagę na potrzebę zdobywania głębszego poznania Boga przez wysiłek intelektualny, ascezę życia, pokorę, odwagę przeciwstawienia się opinii publicznej, obecność przed

\footnotetext{
76 R. Rogowski, Charyzmat teologa, s. 5-17.

77 J. Salij, Sytuacja teologii w Polsce, CT 42(1972) nr 2, s. 85-95. tłum. franc.: J. Salij, Le situation de la Théologie en Pologne, CT 45 (1975) fasc. spec., s. 159-168.

78 K. Góźdź (red.), Leksykon polskich dogmatyków XXi XXI wieku, s. 160-161.
} 
Panem, który przychodzi, wyczucie wiary, spojrzenie na sprawy świata $\mathrm{w}$ perspektywie Boga i ostatecznego spotkania z Nim. ${ }^{79}$

W latach sześćdziesiątych XX w. pojawił się problem kryzysu tożsamości katolickiego teologa dotykający także utalentowanych i cenionych autorów. Odpowiedzią może być codzienna troska o mocną więź z Bogiem i Kościołem jako wspólnotą wierzących.

$$
* * *
$$

Na łamach „Collectanea Theologica” były formułowane istotne zagadnienia teologii dogmatycznej: teologia Miłosierdzia Bożego, wzbogacająca chrystologię refleksja nad czasem, antropologiczne ujęcie mariologii, koncepcja personalizmu jako możliwej drogi odnowy teologicznej, chrześcijańska idea solidarności. Teolodzy proponowali hipotezę istnienia chrztu Kościoła, swoistą teologię ikony, koncepcję Eucharystii uniwersalnej, pytali o cierpienie Boga. Możemy odnaleźć także oryginalne ujęcia teologii przestrzeni, ludzkiej wolności, teologii odpoczynku czy cenne spojrzenie na charyzmat teologa. Już w okresie międzywojennym czasopismo stanowiło miejsce spotkania teologii chrześcijańskiego Zachodu i Wschodu. Niektórzy z dogmatyków publikujących tutaj wyniki swoich badań podejmowali trud konfrontacji zagadnień teologicznych z problemami i rozwiązaniami występującymi w innych naukach. Podjęto próby metodycznie poprawnego i owocnego poznawczo wykrywania i interpretowania specyficznie chrześcijańskich elementów w literaturze pięknej. Historia traktowana była jako żywa rzeczywistość i ciągle aktualna inspiracja. Na kształt publikacji wywarło wielki wpływ wydarzenie II Soboru Watykańskiego, jako wyzwanie do właściwie rozumianej odnowy katolickiej teologii.

$$
\text { ks. Grzegorz BACHANEK }
$$

79 Z. Kijas, Wokót tożsamości teologa w XXI wieku, CT 72(2002) nr 1, s. 100-104. 
Słowa kluczowe: teologia dogmatyczna; Miłosierdzie Boże; personalizm; chrystologia; mariologia

Keywords: dogmatic theology; the Divine Mercy; Personalism; Christology; Mariology

\section{Research Areas of Dogmatic Theology in the Publications in "Collectanea Theologica" 1920-2020}

Summary

The following research areas of dogmatic theology were developed in the publications that appear in "Collectanea Theologica": the theology of the Divine Mercy, the reflection on time which enriched Christology, the anthropological expression of Marian theology, the concept of personalism as a possible way of theological renewal, and Christian solidarity. Theologians proposed the hypothesis of the baptism of the Church, the theology of the icon, and the concept of a universal Eucharist. Among other questions they discussed the notion of the suffering of God. We can also find an original expression of theology of space, human freedom, and the theology of rest as well as a valuable perspective on the charisma of the theologian. Already in the interwar period, the journal was a place of encounter between the theology of the Christian West and that of the East. Some dogmatists, who published the results of their research in the journal, made the effort of confronting the theological topics with the problems and solutions from other branches of scholarship. Attempts were undertaken to explore thoroughly and interpret specific Christian elements in literature. History was treated as a dynamic reality and a source of inspiration for the contemporary world. The Second Vatican Council had a profound influence on the publications, as it provided a challenge to the adequately understood renewal of Catholic theology. 